Folk WAYS. A Study of the Sociological Importance of Usages, Manners, Customs, Mores and Morals. By William Graham Sumner, Professor of Political and Social Science in Yale University. Ginn and Company, Boston.

The psychiatrist is destined to be a leader of the people. In his workshop lie the dismembered parts of mental mechanisms, the study of which constitute his ability to grasp the whys and wherefores of mental reactions. Some of the most elusive factors in this estimation, however, are those ideas held by mankind which in spite of the wisdom of the professors still continue to sway human conduct just as they did in the days of David, of Homer, of Epicurus, of Plato, of Thomas Aquinus, and down to the present day. It is to these folk ways that Dr. Sumner has wisely turned his attention and has given a work which no true student of mental processes would care to overlook.

Adopting the biological point of view the author himself confesses that he must needs go out and gather his material before generalizing. Would that other sociologists might do the same, and some psychologists. He presents a work of 700 pages with 20 chapters, dealing with the fundamental notions of human society. The mores, struggle for existence, labor, wealth, societal selection, slavery, abortion, cannibalism, sex customs, marriage, incest, kinship, blood revenge, the evil eye, harlotry, sports, drama, asceticism, these and others are among the subjects discussedall in a thoroughly simple, first hand manner that is delightful.

The customs that have originated from disease are unfortunately overlooked. No philosopher has yet had the necessary facts and ability to interpret but the time is not far distant when the important relations of disease to social customs and ideas of morality will be written. Even Sophocles would attempt to excuse Ajax for his mad outbreak on the ground of an unknown hereditary factor. In the meantime this work of Sumner's will prove stimulating.

JELIIFFE.

Neurologtcal and Mental Diagnosis, a Manual of Methods. By L. Pierce Clark, M.D., Senior Attending Physician, Hospital for Nervous Diseases, New York; Visiting Neurologist to the Randall's Island Hospitals and Schools, New York, etc.; and A. Ross Diefendorf, M.D., Lecturer in Psychiatry in Yale University; Assistant Physician and Pathologist, Connecticut Hospital for the Insane, etc., New York. The Macmillan Company, 1908. All rights reserved. Price \$r.25 net.

The authors of this practical little volume find justification for its appearance in their statement in the preface that the necessity and desirability of forming correct habits in case examination is in line with the advanced teachings of modern medicine. Definite methods of procedure are laid down in the book both for cases of nervous disease and for those of mental disease, so that a proper analysis may be made, as a matter of routine, either in hospital or private practice. These examinations are both thorough and systematic. There are thirty-one illustrations which are helpful and for the most part original. The chapter on neurological diagnosis is by Dr. Clark and follows largely the scheme of the National Hospital for the Paralyzed and Epileptic of London. The newer "signs and phenomena," as yet unproven, mention of which might confuse the student, have been wisely omitted. Those which are really helpful are 
fully described. The chapter by Dr. Diefendorf on mental examination is on Kraepelinian lines, and is followed by a much-needed glossary of modern psychiatric terms. It is doubtless much more difficult to outline a definite scheme for mental examinations than it is for neurological. Dr. Diefendorf has accomplished much in this direction. May we hope that some day he will give us a tabulated scheme in connection with his excellent descriptions.

\section{Thotes and thews}

An examination will be held on December I5, Ig08, for the position of internes on the staff of the Hospital for Nervous Diseases of the City of New York, which is situated on Blackwell's Island. Two internes to be appointed. All applications should be addressed in writing to Dr. Edward Livingstone Hunt, Secretary, 54 West 5oth St. New York. 